\title{
Traditional Knowledge of Urug Community for Climate, Conservation, and Agriculture
}

\author{
${ }^{1}$ BAHAGIA, ${ }^{2}$ RIMUN WIBOWO, \\ ${ }^{3}$ FACHRUDDIN MAJERI MANGUNJAYA, ${ }^{4}$ OKING SETIA PRIATNA \\ ${ }^{1,4}$ Universitas Ibn Khaldun Bogor and Researcher LPM Equator Bogor, Bogor, Jawa Barat, Indonesia \\ ${ }^{2}$ LPM Equator Bogor, Jl. Sindang Barang No.197 Kota Bogor, Indonesia \\ ${ }^{3}$ Sekolah Pascasarjana Universitas Nasional (UNAS), Jakarta Selatan, Indonesia. \\ correspondence author: bahagiagia59@yahoo.co.id
}

\begin{abstract}
The purpose of this research is to investigate the traditional knowledge of Urug people for climate, conservation, and agriculture. The method use is qualitative with an ethnographic approach. This method is applied because this research is related to social, language, life, and culture of the community. The data are gathered through in-depth interviews, observation, and documentation. The selection of informant wields purposive sampling technique. The triangulation technique is implemented for probing valid data both the technique and sources. The result shows that Urug People observe Kidang constellation for predicting dry season and rainy season. Urug People use languages such as Surut Kidang, Turun Kujang, Surut Kujang, Turun Kungkang as guidance in farming activity. In order to protect nature, Urug People use local languages namely Lebak Balongan, Tebing Awian, titipan, and Gunung Kayuan for conservation of environment. At the same time, Urug people use once a year pattern for planting paddy. Intensive planting is prohibited for giving the soil time to grow and prevent the damage that may occur.
\end{abstract}

Keywords: kidang constellation, community, traditional-knowledge

\section{Introduction}

Indonesia often encounters major hurdles, including ecological disaster and environmental damage. In 2019, a forest fire became a big obstacle due to the hot spot spread that was rampant in Sumatera and Kalimantan Island. Human action was allegedly a causal fundamental factor for around 99 percent of the total number of forest fires cases. Even of total 80 percent of forest fires were plantation areas (Monardo, 2019).

However, indigenous people who have adapted and conducted conservation ecology for a long periode have been neglected. For reducing the ecological environment damage, we need to learn from indigenous people. Local people have valuable action to reduce the degradation of ecology. Local wisdom is a form of knowledge, beliefs, understanding, and customs or ethics that guide human behavior in life and in the ecological community (Keraf, 2006, cited in Mulyadi, 2011). Generally, local wisdom includes the aspects of local knowledge, folklores, religious practices, local beliefs, and also some prohibitions and suggestions (Sumarmi, 2015).

The mixture of knowledge is handed down from generation to generation (Arkanudin, 2009, cited in Siahaya et al., 2016). The practice was related to land use, ecosystem, and environment (Parrotta, 2016). According to Wibowo (2012), local wisdom (traditional wisdom) is the knowledge that has been passed down from generation to generation by the community in managing its environment, namely the behavior resulting from adaptation to the environment and functioning for environmental conservation.

Thus, indigenous knowledge is part of the life of rural communities; their livelihood

Received: 2020-03-28, Revised: 2020-05-05, Accepted: 2020-06-03. 
depends almost entirely on specific skills and knowledge essential for their survival (Githui, David, \& Maurice,2013). Local wisdom includes knowledge passed on from generation to generation, tested, has been adapted for thousands of years, where such knowledge serves as a guide in interacting with the environment (Chianese, 2016).

This knowledge is transmitted through songs or folk tales, observations, and demonstrations (Sithole \& Lekorwe, 2019). This knowledge makes indigenous people able to know about climate conditions, the right time to plant, time to harvest, the time of strong winds occur, temperatures, and animal breeding cycles (Chianese, 2016). This local knowledge is not recorded. For example, time for planting is determined based on the duration and time of rain, observations based on natural appearance, biophysics, beliefs, and experience (Ziervogel \& Opere, 2010, cited in Liang, 2017). Local knowledge also has a connection to life view, knowledge/ science, social and cultural system, and livelihood strategy (Hermanto et al., 2012).

Besides that, local knowledge is the strategy of life locally, such as activity for combating several obstacles in life (Fajarini, 2014, cited in Suyatman, 2018). In addition, nature is a guide, the physical appearance of nature such as the growth of shoots of plants is a sign of the change of seasons from dry season to the rainy season and changes in animal behavior (Dube \& Munsaka, 2018).

In fact, the coming down of various types of wild animals from the top of the mountain is seen as a sign that disaster will come soon (Santoso, Buchari \& Darmawan, 2018). Empirically, local knowledge can refine and preserve environment including water, land, soil, and forest (Anam, Banowati \& Juhadi, 2018). After that, local wisdom is realized by spatial management of forest areas including leuweung kolot (Protected Forest), which is a forest that must not be destroyed at all; leuweung larangan (Forbidden/Buffer Forest), which is a forest where people can go in but only for the custom; leuweung lembur (Production Forest), which is the forest used as production forest products (Maryani \& Yani, 2014).

Besides that, Naga Village conducts forest conservation namely barred forest area (Dewi \& Istiadi, 2016). The zoning of this forest area acts as mitigation of floods, landslides, and droughts. The mitigation of forest fires is carried out with the tradition of Dandangan or mixed with the Ngaduruk tradition. You do this by making a pile in the middle of the field followed by making a small pile around a large pile (Suparmini, Setyawati \& Sumunar, 2013).

This research will investigate traditional local knowledge of Urug community in Bogor Regency West Java. There are several purposes of this research: to find out how Urug people predict both dry and rainy season, to discover the language of local knowledge for conservation of nature and guidance for determining the time to cultivate the paddy, to know how Urug people protect their forest environment, and to find out how Urug people conduct agriculture that is ecologically friendly.

\section{Research Methodology}

The research about traditional knowledge of Urug Community for climate, conservation, and agriculture applies qualitative methods with the ethnography approach. This research is conducted in Urug village, Sukajaya District, Bogor Regency of West Java Indonesia. Qualitative research is applied because researchers require to obtain social situations in actor's view (Afrizal, 2017). Furthermore, qualitative research includes various field notes, interviews, conversations, photos, recordings, and personal notes (Creswell, 2014, cited in Sardi, 2019). Meanwhile, ethnography approach is utilized because it relates to life and cultural of the community (Endraswara, 2015).

The aim of ethnography research is to understand life view base on indigenous people (Spradley, 2006, cited in Oktafia, 2019). Even ethnography have connection to the language of the community as guidance for behavior. The selection of the sample is carried out by using a purposive sampling technique. A sample in this study is a traditional community leader of Urug Community namely abah Ukat.

Abah Ukat is stipulated as a sample for numerous reasons, including that he is the chairman of Urug community. As a leader in a social environment, Abah Ukat is someone who has competent knowledge compare to other persons in Urug. It is appropriate to make him a sample because he is the most knowledgeable person (Sugiyono, 2010).

Another sample is Abah Maman who becomes exemplary for Urug people in terms of behavior. Besides that, abah Ukat also 
believes abah Maman as a sample to explain agriculture activity. Data are collected through in-depth interviews with Abah Ukat and Abah Maman.

In depth interviews are conducted to obtain relevant data including local knowledge of Urug people for determining drying season and wet season, information related to local language as references for conservation of nature, and references in agriculture production. When the interview is held, the researcher takes notes and records the voice of the sample. Besides that, observation is done upon the situation in the vicinity of Urug people, such as forbidden forest or mountain area, the rice paddy field, traditional paddy storage to see local variety, and ceremonial day of Urug people (Sedekah Bumi and Saren Taun).

While secondary data was obtained from the article journal and books that are connected to traditional knowledge. The data are probed meticulously by triangulation data for getting valid data. There are two sorts of triangulation, including techniques and sources (Sugiyono, 2010). In this research, the triangulation technique combined data taken from observation, in-depth interviews, and documentation. Triangulation technique is strengthened by triangulation sources, which includes in-depth interviews with two persons as sources namely abah Ukat and abah Maman. The aim of this action is to ensure that the information from both samples have a strong similarity. The outcome of both triangulation can be considered as reliable data.

\section{Results and Discussion}

\section{Local Knowledge For Protecting Nature}

Urug people perceive that nature is Tititapan or amanah (mandate) from their predecessors. As titipan, human has obligations to protect nature from wicked people, especially mountain area because we save our nature now for the next generation.

Abah Ukat as leader of Urug people said that Gunung Kayuan, lamping awiyan, legok balongan are related to the behavior where nature including forest, river, mountain, and land should be kept from damage. The meaning of the words above can be seen in Table 1.

Each point has a strong value to keep nature. Titipan, meaning that people, especially Urug people, have the nature guarantee for life. The responsible also continue to the young generation in Urug community. They convince that each person inside or outside the community has a duty to take care of nature. All generations have the same duty on earth, namely to protect nature.

According to abah Ukat as a leader of local people, they never cut down the trees. All people are convinced that if they cut trees in the forest and kill animals, they will have a hard time so that people don't have the courage to break the rule. Even the individual belief that various of catastrophe can occur because the generation has the nerve to breach the treaty between them and their ancestors which can be pursued until the next generation. People from outside the tribe must also obey these rules. Other than that, Lamping Awiyan, it is located in the valley. In this location, there must be vegetation such as bamboo to dwindle the rate of land sliding.

Roots of bamboo is strong to retain the soil. The size of bamboo roots is small but it is powerful to protect the land from sliding when rainy and dry season coming. In addition, Legok Balongan is similar to the water basin. Each water basin gets the water naturally from the rain.

Water spring stream at every basin will

Table 1

Basic Viewpoint of Urug People for Preserving the Nature

\begin{tabular}{|c|c|c|c|}
\hline No & Sundanese Language & Indonesian Language & English Language \\
\hline 1. & Titipan & Amanah & $\begin{array}{l}\text { Humans are responsible for protecting } \\
\text { nature }\end{array}$ \\
\hline 2. & Gunung Kayuan & Gunung Berkayu & $\begin{array}{l}\text { Mountain area as the place for wood } \\
\text { to grow }\end{array}$ \\
\hline 3. & Lamping Awiyan & Lembah ditumbuhi bambu & Valleys where bamboo grow \\
\hline 4. & Legok Balongan & Lembah yang berair & water basin as reservoir of water \\
\hline
\end{tabular}


not termish in the dry season. It is unlike the modern water reservoir which plays a role as a giant reservoir. At least there are two roles of Legok Balongan: for mitigation of community from a scarcity of water as wells as salvage the Urug people from flooding and slide disaster.

The shortage of water is rare in the location because they deposit water in the water reservoir as water stock in the dry season. It can lead to rekindling water spring around river, hill and at top of mountain. While in the rainy season, rainwater will not jump quickly to low land area.

The water pass bendungan (dam) toward another low land area. It results on reducing the speed of rainy stream. The impact is, there will be flooding. Another reference is Gunung Kayuan. Each mountain must be sprouted by trees. People of Urug have pledged to protect all mountains, such as Manapa mountain in Urug. Wet season may cause a landslide. Fortunately, Urug people have the best local knowledge to keep the forest. They create Forbidden forest that is a forest zonation with numerous functions. In forbidden forest, the vicinity of the mountain, the people are totally banned to enter this area. All wildlife especially animals, leaves, and stumb decay may not be gathered by people but the leader can have permit to enter this area. The leader convinces that forest can keep the water because trees and various bushess assist the water to save in the underground.

Besides that, several animals such as eagle and squirrel use this zonation for nesting. Even birds use it as feeding zonation because there are variety of insects as a fundamental source of food. Snakes and lizards are also found around the location.
Hence, rice fields which located on the hill of the mountain can get water from the upstream of the mountain.

It is also valuable for people because the water in well will be abandoned both in the dry season and rainy season. This finding strengthened by other similar findings in kampung Naga that splitted forest zonation into Keramat (holy forest) and Larangan (forbidden) Forest. Local people in kampung Naga also renowned for "leuweung mah imah kai, kai mah imah cai (Forest is a house of water)", which means that local people understand that forest has water sovereignty (Dewi \& Istiadi, 2016). The zonation of a sacred location is utilized by animals as their habitat (Iloka, 2016).

\section{Local Knowledge For Predicting Climate and Timing For Cultivating}

The universe is the best teacher for Urug people. They reveal each signal from nature to determine season and climate. Season both dry and rainy season can be predicted by them. Unfortunately, mitigation of climate change base on technology or the process on top-down action.

It would be better if science and local knowledge work together to produce the best climate planning (Kpadonou, et al. 2012). Urug people observe the sky and notice Kidang constellation at night. They use nature phenomena such as Kidang constellation as their guidance to do actions in life.

The emerge of Kidang constellation is an indicator for Urug community to decide timing for cultivating the rice fields. Abah Ukat remarked that "Surut Kidang Turun Kujang", "Surut Kujang turun kungkang". "Surut Kungkang Padi berbuah". The complete

Table 2

Poet Language of Urug Community to Forecasting Climate and Planting Season

\begin{tabular}{|c|c|c|c|}
\hline No & Sundanese Language & Indonesian Language & English Language \\
\hline 1. & Surut Kidang & $\begin{array}{l}\text { Bintang Kidang Berada di } \\
\text { Kawasan Barat }\end{array}$ & $\begin{array}{l}\text { Kidang constellation is on west } \\
\text { zonation }\end{array}$ \\
\hline 2. & Turun Kujang & $\begin{array}{l}\text { Kujang adalah senjata } \\
\text { tradisional Jawa Barat, } \\
\text { Indonesia Traditional Tool in } \\
\text { West Java Indonesia }\end{array}$ & $\begin{array}{l}\text { Kujang is traditional weapon in } \\
\text { West Java Indonesia This looks } \\
\text { like a proverb to indicate that } \\
\text { people in Urug have provided } \\
\text { traditional tool for agriculture } \\
\text { production such as sickle, hoe, } \\
\text { seed, and tractor, cows, tiller, and } \\
\text { other agricultural planting action. }\end{array}$ \\
\hline 3. & Turun Kungkang & $\begin{array}{l}\text { Kemunculan serangga, tikus, } \\
\text { dan berbagai bencana. }\end{array}$ & $\begin{array}{l}\text { The appearance of various } \\
\text { insects, mouse, and ecology } \\
\text { disaster. }\end{array}$ \\
\hline
\end{tabular}


explanation is in the Table 2 .

Sundanese tribe called it Kidang constellation, while Javanese called it Waluku constellation. Kidang constellation is three stars that emerged in the east to west (from wetan to kulon in Sundanese language) and run together from east to west. We can't view Kidang at noon, but people can see Kidang constellation at night because the shine of the star is weakened by the sunshine at noon.

The rising of star in the East has related meaning to the beginning of the dry season. Udin as an expert in traditional agriculture explained that the dry season will come when the Kidang constellation arises in the East. At this time, both rainy and dry season still come but dry season continues to be dominated. Conversely, when the position of Kidang constellation is in the West, the rainy season will begin to pour.

The period comprises three levels of swelter when Kidang reaches the East zone. People will get swelter at noon if the position of Kidang constellation at 10 a.m. or 21 p.m. at night in the sky. The environment will not be too swelter and not too cool. The rate of heat may jump when Kidang constellation moves at 22 .p.m. at night or 11 a.m. at noon.

The heavy swelter level will occur when the position of Kidang constellation is on top of our head. In this position, the human will be sweating a lot caused by the sunshine. Kidang constellation will stay right on top of our head for 40 days. However, rain can fall when Kidang constellation is at 1 a.m. or 13.00 p.m. The rain time can also be pursued at 14 p.m. The schedule for the first seedling is when the Kidang constellation moves to the East.

People have to provide local paddy seeds for seedling when Kidang constellation has shifted to $15-16.00$ p.m. in the west site. At the same time, Urug people release Sedekah Bumi or reward for the earth. Sedekah Bumi looks like admission or Ceremonial paddy open from the leader of Urug community namely Abah Ukat. No one will be allowed to cultivate several plants like paddy before they have a permit from Abah Ukat.

Sedekah Bumi must be conducted before cultivating paddy in wet rice fields. It is an extraordinary day because all people in Urug community visit the house of the leader namely Gedong House. The house is significantly different from another house because it is made by a wooden wall and palm roof. They begin Sedekah Bumi after all people have attended.

The leader comes and prays together asking for prosperity, life security, food sovereignty, and for protecting their lives from catastrophe. If this step has taken, all the members of Urug tribe will initially take paddy seed from Leuit. In Urug person, Leuwit (traditional building used for rice storage) has two roles, namely for seed and consuming. They will take paddy seed that they have been selected naturally before.

People in Urug perceive that the paddy on top of the layer of the Leuit will be appropriate to be used for seed but they did not choose the seed from the field because paddy is in good condition overall. In 40 day later, the seedling is ready to move onto the land. Another activity is Tandur Season. Tandur in Urug community means to cultivate. This period must be conducted after the position of Kidang constellation at 5 a.m or 17.00 p.m.

In addition, the wet paddy field has been provided amid Kidang constellation on top of our head and Sedekah Bumi ceremony. The land has to be ready at least 1 month before the planting schedule. The environment will not lack of water when planting time adheres to this wave season. The movement of Kidang constellation continues until people can't view the constellation anymore at night.

At this time, the environment will not experience water shortage because the rainy season is quite heavy but the paddy has reacted properly. They assert that paddy is in 40 ages when Kidang constellation vanishes from the sky. At the same time, base on Urug people's observation, natural enemies for paddy such as mouse will be in their nest when Kidang constellation can't be viewed.

In contrast, birds fly away from their nests to go to wet rice land. Unfortunately, the birds are unable to consume paddy straw for the paddy have not produced fruits yet. All birds return to their nest naturally or looking for other sources of food. After the birds leaving the location, paddy is in the flowering period in Mei.

Rats invade the wetland of paddy but they can't consume the plant because paddy straw is quite hard to bite. Thus, they cut the paddy straw before it collecting paddy grains. When paddy is growing, rats can't collect paddy grain because they will not chop paddy straw. Rats failed to get food this time, so they 
return to their nest.

At the same time, Kidang constellation will appear again in the East location after paddy is about to harvest time or paddy grains have already matured. They estimate that the time will be in June-July at 10 a.m or 22.00 p.m. at night. Here, the rainy season has stopped and changed to dry season again. Agricultural production has not stopped until paddy has gathered from the land but to pursue the Saren Taun moment (Ceremonial After Harvest) or Closing Ceremonial.

Different from Sedekah Bumi, in Seren Taun Urug people, convinced that the whole activity in agriculture will obtain fortune if they follow the rules. Even the paddy will not be attacked by kungkang. In the Sundanese term, kungkang refers to insects or other creatures that potentially become foe for humans and paddy.

Pests are enemies for plants and farmers. There is a significant relationship between seasons and the huge of insects. Abah Ukat, the leader of kampung Urug, said that the wind blows from the West to the East at that time will demolish the insects due to storm, rain, and heavy wind flow. There are numerous insects that died when heavy rain coming, such as kutu-kutu, grasshopper, other and small insects.

Insects that can be consumed and planthopper insects are the prominent enemies for farmers in Indonesia. The type of this insect can be eliminated by nature because these sorts of insects are small and light which would be so easy to be vanished by the hard wind. In this time, Urug people don't need to spray the pesticide because such insects are rarely found in the location.

As a result, it is valuable and satisfying for Urug people that they can get paddy yields. In the contrary, when Kidang constellation appears in the East zone and the farming activity is conducted by a peasant, they Numerous of planthopper insects and rats will give difficulties to farmers because the movement of the wind is not as fast as the wind under the Kidang constellation that rises in the West location. The pests are there in the paddy field because there is no nature power that can kill them immediately. Even rainfall is not as often as when Kidang constellations is in West region so that there is no nature energy that can wash away those pests from paddy plants.

As a consequence, paddy yields cannot be saved by a farmer. Insects will damage the paddy, and paddy flowers will fall. Even unfriendly actions such as the overuse of pesticides can't dwindle insects' attack. The impact that can occur is environmental damage because the wielding of the chemical has strong potential to noxious the soil, spring water, water, and the air.

Abah Ukat ended the conversation by advising that farmers in Indonesia should stop cultivating more than twice a year. Abah said that in the future, many people are at risk of hunger if they don't adhere to season wavelike Urug people's behavior. Abah Ukat told a sample that farmers will fail to grow paddy when they ignore the appropriate timing for planting.

\section{Knowledge in Sustainable Agriculture}

Urug communities have acted to protect ecology function such as preserving soil fertility from damage. They conserve nature because nature will salvage their subsistence by doing agriculture activities. Abah Ukat as the main leader in Urug Community revealed that there are numerous ways to conduct sustainable agriculture.

First of all, based on an interview with abah Ukat, Urug people have the fundamental principle that they decide never to cultivate paddy more than three times in a year. They do it just once in a year. In their experience, when planting paddy on land more than three times or four times in years, the soil will lose its fertility rate. Abah Ukat said that when people are enforced to work without resting, they will lack the energy to continue working and can't finish the activity.

Soil is like humans when the land is cultivated regularly or intensively more than one time in a year, its fertility will extinguish sharply in a long period. The factory of manure should add more to increase the rate of land fertility because it has been dwindled due to intensive planting. The impact is that farmers will fail to get income from agriculture.

Abah remarked that they perceive soil needs to take a rest from planting activities. Land need to let bushes, trees, and grass to grow before being planted again in the next season. The soil will be in a good condition again if the fertile can recharge again naturally. The merit for humans is to gain stable production in the long future to get a 
stable outcome.

Sustainable behavior like this is similar to LEISA (low External input of agriculture). At the same time, LEISA can optimize local resources with farming combination behavior and adopt outside resources as complementary to reduce environmental damage (Asandhi, 2005 cited in Nuraini et al., 2015).

Conversely, Indonesia has implemented three times a cultivating period each year. Abah Ukat said this behaviour will be dismerit for farmers in a long future because soil will not fertile again. As a consequence, farmers have to over-use the manure for increasing the fertile level. The negative impact from this method can contribute to the number of emission gases.

It can be compounded by the degradation of soil fertility when organic manure are applicated (Simanjuntak, Lahay \& purba, 2013). The other impact is that organic fertilizers contribute to the production of greenhouse gases globally because it is a source of nitrous oxide (N2O) production (Erbas and Solakoglu, 2017).

The other detrimental impact is that non-organic fertilizer can increase aphids assault instead of organic manure (Morales et al., 2001 cited in Harrison, 2019). In the contrary, adopting organic fertilizer can ameliorate crop yield, despite the higher pressure of insects, the result is it can improve plant growth (Vanlauwe et al., 2014 cited in Harrison, 2019).

Another principle is that Urug community uses local paddy variety. There are varieties in Urug including Sri Kuning, Raja Wesi and Ketan Gadok. It can distinguish significantly to national variety in Indonesia such as IR 64, Fatmawati, and Ciherang. The usage of local variety is a way to conserve local paddy variety (Iskandar \& Iskandar, 2018). The stamp paddy is higher than the national type of variety, which is paddy grains are longer, there is long tail at each paddy grains and grains panicles. What is more, is the number of grains in panicles is more than national paddy variety.

Another advantage is that the grains will not easy to fall out from the panicles. Grains can retain at panicles when hard wind and rain smash paddy plants. The reason is strengthened by abah Maman as an agricultural expert from Urug people. The outcome from farmer activity such as growing national paddy will obtain lower yield instead of planting local paddy due to the number of paddy grains of national paddy are not as much as local paddy.

Furthermore, paddy grains are hard to fall out although the storm smashes the rice straw. It can be valuable because yields can be assisted by disasters such as strong wind blow and heavy rain. The farmer will not experience detrimental for these occurrences but they gather value. The other benefit is that the taste of national paddy is not as delicious as variety they have. Even a modern variety of paddy is easier to decay in-store rather than local paddy, that is why they reluctant to adopt the national paddy.

Besides that, Abah Ukat said that Urug people have appointed the time for harvesting. They commonly grow paddy in June to December and January to December but two times a year still uncommon for them. There are some reasons why they hate to plant out of their schedule time. They believe rats will not attack the paddy when cultivating according to their time because the rats are still in their nest. People in Urug community have monitored that this period is the best time for cultivating, as it shown in table 3 .

Basically, Urug people reluctant to plant twice a year because their predecessors have taught them to plant one time in a year. Nevertheless, when people must grow paddy in this pattern, farmers have to proof that they have picked paddy in June-July and November-December. Although Abah Ukat still

Table 3

Schedule of Paddy Planting according to Indigenous Urug People

\begin{tabular}{lll}
\hline Cultivating Period & Harvesting Period & The Type of paddy \\
\hline End of March & June-July & $\begin{array}{l}\text { Paddy of } 100 \text { ages from government (IR 64, } \\
\text { Ciherang, Fatmawati, etc). }\end{array}$ \\
End of July & November-December & $\begin{array}{l}\text { Paddy of } 100 \text { ages from government (IR 64, } \\
\text { Ciherang, Fatmawati, etc). } \\
\text { February }\end{array}$ \\
July-August & $\begin{array}{l}\text { Local paddy in Urug such as Raja Wesi, Ketan } \\
\text { Gadog, and Sri Kuning. }\end{array}$ \\
\hline
\end{tabular}


uses a one-time pattern for paddy planting, people plant paddy at the end of February each year and paddy can be collected in the field 6-7 months later on July-August.

If the people plant outside of this schedule, the peasant will fail to gather the yield. According to abah Ukat, local people hate to plant modern variety. Nowadays, there are various patterns for cultivating in Urug people. In the following manner, when people decide to do paddy production twice a year, they must take paddy panicles at the same time as Urug leader. Abah Ukat has encouraged his people to adhere to the government. The most important thing is those who adopt two times pattern of paddy planting have to conform with those who apply a one-time pattern.

Abah Ukat will tolerate the person in his community to break the rules for paddy production at one time in a year. Meaning that people who do this time must assert that they plant paddy later after the leader of the community plant the paddy. Both of these patterns will meet later for harvesting schedules because the paddy variety from the government has shorter ages rather than local paddy. For Instance, paddy variety from the government such as IR 4 has 100 day/4 months until people can get the yields.

Conversely, local paddy has a longer time for harvesting about 7 months after seedling. Abah Ukat initially plants the paddy in February 2020 and time for harvesting will be in July-August. People who don't follow this pattern, they have to plant in April 2020 and for taking paddy yields in July-August.

\section{Conclusions}

Based on the discussion above, the result of research can be concluded as follow:

Indigenous people of Urug have traditional knowledge that can predict climate both dry season and rainy season. When the Kidang constellation rises in the east, the dry season begins. Conversely, when the star is in the west side, the rainy season comes. The emergence of the Kidang has meaning, which is the community will start planting rice and plants when the position of the star Kidang is in the west. Meanwhile, when the harvest season arrives, the position of the Kidang star rises to the East. At that time, all agricultural equipment had begun to be stored. Then, pests came to the land but insects were unable to damage it because the rice harvest has been completed.

There are numerous of principles in ecosystem protection starting from gunung kayuan (every mountain area must not be damaged, lamping awiyan (every valley area must be planted with bamboo), and legok balongan (watery area must be preserved).

Urug indigenous people preserve forests by creating prohibited forest (hutan larangan) areas and awisan forests, where no people are allowed to damage the forest. (4) Indigenous peoples have never planted rice two or three times a year. Urug people have knowledge that the more land is planted, the greater the loss of soil fertility; the land needs a rest from planting with the goal is to restore soil fertility.

\section{References}

Afrizal. (2017). Metode Penelitian Kualitatif, Sebuah Upaya Mendukung Penggunaan Penelitian Kualitatif Dalam Berbagai Disiplin Ilmu. Jakarta: PT. Raja Grafindo Persada.

Anam, C., Banowati, E., \& Juhadi. (2018). Kearifan Lokal Masyarakat Kandri dalam Konservasi Sumber Daya Air Gunungpati Semarang. Jurnal I/mu Sosial Pendidikan, Vol. 7, No. 2, pp. 154-160.

Chianese, F. (2016). The traditional knowledge advantage: Indigenous peoples' knowledge in climate change adaptation and mitigation strategies. India: International Fund for Agricultural Development (IFAD).

Dewi, I.K., \& Istiadi, Y. (2016). Mitigasi Bencana di Komunitas Tradisional dalam Menangani Perubahan Iklim di Kampung Naga, Kecamatan Salawu, Kabupaten Tasikmalaya (Disaster Mitigation on Traditional Community Against Climate Change in Kampung Naga Subdistrict Salawu Tasikmalaya District). Journal Manusia Lingkungan, Vol. 23, No.1, pp. 129-135.

Dube, E. \& Munsaka, E. (2018). The contribution of indigenous knowledge to disaster risk reduction activities in Zimbabwe: A big call to practitioners. Journal of Disaster Risk Studies, Vol. 10, No. 1, pp.1-8.

Endraswara, S. (2015). Etnologi Jawa. Yogyakarta: Center of Academic Publishing Services.

Erbas, B.C., \& Solakoglu, E.B. (2017). 
In the Presence of Climate Change, the Use of Fertilizers and the Effect of Income on Agricultural Emissions. Jurnal Sustainability, Vol. 9, pp. 1-17.

Githui., David, N., Maurice, S. (2013). The Role Of Indigenous Knowledge In Socio- Economic Development Wangu. International Journal of Science and Research (IJSR), Vol. 4, No. 4, pp.32-37. Harrison, R., Thierfelder., Baudron, C., Chinwada, P., Midega, C., Schaffner, U., van den Berg, J. (2019). Agro-ecological options for fall armyworm (Spodoptera frugiperda JE Smith) management: providing low-cost, smallholder friendly solutions to an invasive pest. Journal of Environmental Management, Vol. 243, No. 23. pp. 318-330.

Hermanto., Pasya, G.K., Muchtar, S.A., Sumaatmadja, N. (2012). Filosofi Hidup Sebagai Basis Kearifan Lokal (Studi Pada Kesatuan Masyarakat Adat Kasepuhan Banten Kidul). Jurnal Pendidikan Geografi, Vol. 12. No. 1, pp. 1-14.

Iloka, N.G. (2016). Indigenous Knowledge For Disaster Risk Reduction: An African perspective, Journal of Disaster Risk Studies, Vol. 8, No.1, pp. 1-7.

Iskandar, J., \& Iskandar, B.S. (2018). Kearifan Ekologi Orang Baduy Dalam Konservasi Padi Dengan "Sistem Leuit". Jurnal Biodjati, Vol. 2, No.1, pp. 38-51.

Kpadonou, R.A.B., Adégbola, P.Y., \& Tovignan, S.D. (2012). Local Knowledge And Adaptation To Climate Change In Ouémé Valley, Benin. African Crop Science Journal, Vol. 20, 181-192.

Liang, S. (2017). Incorporating Indigenous Knowledge in the Local Government's Warning System. Lund University's Faculty of Engineering Division of Risk Management and Societal Safety.

Maryani, E, \& \& Yani, A. (2014). Kearifan Lokal Masyarakat Sunda dalam Mitigasi Bencana dan Penerapannya Sebagai Sumber Belajar Berbasis Sosial. Jurnal Penelitian Pendidikan, Vol. 14, No.2, pp. 114-125.

Monardo, D.(2019). BNPB: 80 Persen Lahan Terbakar Berubah Jadi Lahan Perkebunan.(https://nasional.kompas. com/read/2019/09/18/09532771/bnpb80-persen-lahan-terbakar-berubah-jadilahan-perkebunan) diunduh 18 September 2019.

Mulyadi. (2011). Pengaruh Kearifan Lokal, Lokus Kontrol, dan Motivasi pada Perilaku Wawasan Lingkungan Petani dalam Mengelola Lahan Pertanian di Kabupaten Soppeng (Upaya Lokal II / Isdom, Lokus
Kontrol, dan Motivasi Melestarikan Lingkungan terhadap Perilaku Berorientasi Lingkungan Petani) dalam Mengelola Lahan Pertanian di Kabupaten Soppeng). Jurnal Manusia dan Lingkungan, Vol. 18, No.1, pp. 60-67.

Nuraini, A., Yuwariah, Y., \& Rochayat, Y. (2015). Pengembangan Produksi Pertanian Lahan Kering Dengan Sistem Low External Input Sustainable Agriculture (Leisa) Di Desa Cigadog, Dan Mandalagiri Kecamatan, Leuwisari Kabupaten Tasikmalaya. Jurnal Aplikasi Ipteks Untuk Masyarakat, Vol. 4, No.2, pp. $113-118$.

Oktafia, L.H.W.(2019).Kajian Etnografi Tradisi Sungkem Trompak Di Desa Pogalan Kabupaten Magelang (Kearifan Lokal Dan Konservasi Lingkungan). Skripsi, Jurusan Aqidah Dan Filsafat, Fakultas Ushuluddin Dan Humaniora, Universitas Islam Negeri Walisongo Semarang.

Parrotta, J., Youn., Yeo-Chang., Camacho., \& Leni D. (2016). Traditional knowledge for sustainable forest management and provision of ecosystem services. International Journal Biodiversity Science, Ecosystem, 12 (1). https://doi.org/10.10 80/21513732.2016.1169580.

Santoso M.B., Buchari A., Darmawan, I. (2018). Mekanisme Masyarakat Lokal dalam Mengenali Bencana di Kabupaten Garut, Jurnal Social Work, Vol. 8, No. 2, pp. 142-149.

Sardi, D., Sarwoprasodjo, S., Lubis, S.D.H., Suharjito, D. (2019). Kearifan Lokal: Sebuah Analisis Sosiologi Komunikasi Di Manggarai Barat (Local Wisdom: A Sociology Of Communication Analysis In West Manggarai). Sodality: Jurnal Sosiologi Pedesaan, Vol. 7, No. 2, pp. 136-142.

Siahaya, M.E., Hutauruk, T.R., Aponno, Hendrik, S. E. S., Hatulesila, J.W., Mardhanie, A. B. (2016). Traditional Ecological Knowledge On Shifting Cultivation And Forest Management In East Borneo, Indonesia. International Journal of Biodiversity Science, Ecosystem Services \& Management, Vol. 12, No.1-2, pp. 14-23.

Simanjuntak, A., Lahay, R.R., Purba, E. (2013). Respon Pertumbuhan Dan Produksi Bawang Merah (Allium Ascalonicum L.) Terhadap Pemberian Pupuk Npk Dan Kompos Kulit Buah Kopi. Jurnal Online Agroekoteknologi, Vol.1, No.3, pp.362373.

Sithole, A., \& Lekorwe, M. (2019). Women's Use of Indigenous Knowledge Systems To 
Cope With Climate Change, Advances in Social Sciences Research Journal, Vol. 6, No.6, pp. 111-119.

Sugiyono. (2010). Metode Penelitian Pendidikan, Pendekatan Kuantitatif, Kualitatif dan R \& D. Bandung: ALFABETA.

Sumarmi, S. (2015). Local Wisdom of Osing People in Conserving Water Resources. Jurnal Komunitas, Vol. , No.1, pp. 43-51. Suparmini., Setyawati, S., Respati,D., Suryo, S. (2013). Mitigasi Bencana Berdasarkan Kearifan Lokal Masyarakat Baduy. Jurnal
Penelitian Humaniora, Vol. 19, No.1, pp. 47-64.

Suyatman. U. (2018). Teologi Lingkungan dalam Kearifan Lokal Masyarakat Sunda. Jurnal Peradaban Islam, Vol.15, No.1, pp.77-88.

Wibowo H.A, Wasino, Setyowati D.L. (2012). Kearifan Lokal dalam Melindungi Lingkungan (Studi Kasus Masyarakat di Desa Colo, Kecamatan Dawe, Kabupaten Kudus). Jurnal IImu Sosial Pendidikan, Vol. 1 , No.1, pp. 25-30. 